\title{
A Study on Variations of Nutrient Foramen of Fibula in Saurashtra Region with its Clinical Relevance
}

\author{
Vraj J Akbari ${ }^{1}$, Sanjay R Chavda ${ }^{1}$ \\ ${ }^{1}$ Assistant Professor, Department of Anatomy, P.D.U. Medical College, Rajkot - 360001, Gujarat, India,
}

\section{Abstract}

Introduction: Nutrient foramen is an opening into shaft of fibula which gives passage to the blood vessels of medullary cavity. The knowledge of nutrient foramen is important in surgical procedures like bone grafting and more recently in microsurgical vascularized bone transplantation. Objective: To determine the number, location and direction of nutrient foramen and whether the nutrient foramens obey the rule of ossification, that is directed away from the growing end of the bone or not. Subjects and Methods: The present study consisted of 150 (75 right and 75 left) dried fibula bones excluding any fracture or pathological abnormalities Number and direction of nutrient foramen was observed in each fibula. Location of nutrient foramen in relation with surfaces and zones of fibula was determined. Results: It has been observed that $96.67 \%$ of the fibula had a single nutrient foramen, 3.33\% double foramen and no bone had 0 nutrient foramen. It was concluded that $98.71 \%$ of the nutrient foramina were present on the posterior surface and $1.29 \%$ on medial crest. It was also concluded that most $(98.06 \%)$ of the foramina present in the zone II followed by zone III $(1.29 \%)$ then by zone I $(0.65 \%)$. All foramina were directed toward the upper end of fibula. Conclusion: By knowing the number and location of the nutrient foramina in fibula would be useful in preventing intra-operative injury of nutrient artery during orthopedic, plastic and reconstructive surgery and will also be relevant in medico legal practice.

Keywords: Clinical implications, foraminal index, fibula, nutrient foramen.

Corresponding Author: Dr. Sanjay R Chavda, Assistant Professor, Department of Anatomy, P.D.U. Medical College, Rajkot - 360001, Gujarat, India.

Received: March 2019

Accepted: March 2019

\section{Introduction}

Nutrient foramen is an opening into the shaft of fibula bone. It leads to oblique nutrient canal passing through cortex and ultimately opens into the medullary cavity. The nutrient artery enters into the medullary cavity through nutrient foramen and the canal which is a rich source of blood supply to the medullary cavity and inner two-third of cortex of the fibula. ${ }^{[1]}$

The nutrient blood supply is crucial for any long bones and it should be preserved in order to promote the fracture healing. ${ }^{[2]}$ Moreover, the presence of preserved nutrient blood supply is essential for the survival of the osteocytes in cases of tumor resection, trauma, and congenital pseudoarthrosis. ${ }^{[3]}$

It is usually single in number and located on the posterior surface of the fibula. It is usually directed toward the upper end of fibula away from growing end. ${ }^{[4]}$ The number and location of foramina remains are non-constant feature in long bones. ${ }^{[5]}$ Henderson RG also reported that their location in mammalian bones are variable and may alter during the growth. ${ }^{[6]}$ Knowledge of the number and location of nutrient foramina is useful in certain surgical procedures. ${ }^{[7]}$
Studies on the vascularization of long bones of various populations were conducted analyzing the nutrient foramina morphometry and the vascular anatomy in reconstructive surgeries. ${ }^{[8-11]}$

Therefore, the aim of this study was to study the precise anatomy of nutrient foramina in adult human fibula of saurashtra region. This knowledge was of tremendous significance to orthopedic surgeons performing procedures involving bone grafts, fracture repair, joint replacement and vascularized bone microsurgery.

\section{Subjects and Methods}

Study was conducted in the Department of Anatomy, P.D.U. Medical College Rajkot, Gujarat, India and GMERS medical college, Junagarh, Gujarat, India. Total 150 adult human cleaned and dried fibula bones were included in the study. All selected bones were normal with no appearance of pathological changes. The specific age and sex characteristics of the bones studied were unknown. The nutrient foramina were observed in all bones with the help of a hand lens. They were identified by the elevated margins and by the presence of a distinct groove proximal to them. Only well-defined foramina on the diaphysis were accepted 


\section{Akhari d Chavda, Variations of Nutrient Faramen of Filula in Saurashtra Regian}

for present study. Foramina at the ends of the bones were ignored. Foramina smaller than a size 24 hypodermic needle were considered secondary and these were not analyzed or reported in this study. The position of all nutrient foramina was determined by calculating the foraminal index (FI) using the formula: $\mathrm{FI}=(\mathrm{DNF} / \mathrm{TL}) \times 100$ where $\mathrm{DNF}$ is the distance from the proximal end of the bone to the nutrient foramen; TL is total bone length [Figure 3]. The position of the foramina was divided into three types according to FI as mentioned below. Type - 1: FI below 33.33, the foramen was in the proximal third of the bone. Type - 2: FI from 33.33 up to 66.66 , the foramen was in the middle third of the bone. Type - 3: FI above 66.66, the foramen was in the distal third of the bone. All measurements were taken to the nearest $0.1 \mathrm{~mm}$ using vernier caliper 2 . The observations and measurements were presented in descriptive statistics.

\section{Results}

The following observations were found to conclude the results of the study.

\section{Number of foramina}

As shown in [Table 1], the single nutrient foramen was present in $97.33 \%$ (73) of right fibula and $96 \%$ (72) of left fibula, double nutrient foramina in $2.67 \%(02)$ right fibula and $4 \%$ (03) of left fibula. The nutrient foramina were found to be absent in 0 right fibula and 0 of left fibula.

It has been concluded that $96.67 \%$ of the fibula had a single nutrient foramen. The double foramen was observed in $3.33 \%$ of the fibula. 0 of fibula had no nutrient foramina.

Table 1: Number of nutrient foramen of Fibula

\begin{tabular}{|l|l|l|l|l|l|l|}
\hline $\begin{array}{l}\text { No of } \\
\text { nutrient } \\
\text { foramen }\end{array}$ & Right & Left & & Total & \\
\hline & $\begin{array}{l}\text { No of } \\
\text { Fibula }\end{array}$ & $\%$ & $\begin{array}{l}\text { No of } \\
\text { Fibula }\end{array}$ & $\%$ & $\begin{array}{l}\text { No of } \\
\text { fibula }\end{array}$ & $\%$ \\
\hline 0 & 00 & 00 & 00 & 00 & 00 & 00 \\
\hline 1 & 73 & 97.33 & 72 & 96 & 145 & 96.67 \\
\hline 2 & 02 & 2.67 & 03 & 4 & 5 & 3.33 \\
\hline Total & 75 & 100 & 75 & 100 & 150 & 100 \\
\hline
\end{tabular}

\section{Location of foramina}

It has been observed that a total of 155 numbers of nutrient foramina were found to be present in all studied fibula. In relation to surfaces, it was found that posterior surface had $98.70 \%$ (76) of nutrient foramina in right fibula and $98.72 \%$ (77) of nutrient foramina in left fibula, median crest had $1.30 \%(01)$ of nutrient foramina in right fibula and $1.29 \%$ (02) of nutrient foramina in left fibula were found as shown in [Table 2].

Therefore, it was concluded that the majority $98.71 \%$ of the nutrient foramina were found to be present on the posterior surface of the shaft of fibula, followed by $1.29 \%$ of the nutrient foramina were concentrated on the median crest of the shaft of fibula.

As shown in [Table 3], the incidence of nutrient foramina present in Zone I of the shaft of fibula was found to be $0 \%$ (0) in right fibula and $1.28 \%(1)$ in left fibula. It was observed that 75 nutrient foramina $(97.4 \%)$ were present in Zone II of right fibula and 77 nutrient foramina (98.72\%) in Zone II of left fibula. It was also observed that 2 nutrient foramina $(2.6 \%)$ were present in Zone III of right fibula and
0 nutrient foramina $(0 \%)$ in Zone III of left fibula in relation to the zones

Overall incidence of presence of nutrient foramina in the middle one-third or Zone II of the shaft of fibula were $98.06 \%$, followed by the lower one-third or Zone III (1.29\%) and by upper one-third or zone I $(0.65 \%)$.

Table 2: Location of nutrient foramen of Fibula
\begin{tabular}{|l|l|l|l|l|l|l|}
\hline $\begin{array}{l}\text { Locatio } \\
\text { n }\end{array}$ & \multicolumn{2}{|l|}{ Right fibula } & \multicolumn{2}{l|}{ Left fibula } & \multicolumn{2}{l|}{ Total fibula } \\
\hline & $\begin{array}{l}\text { No of } \\
\text { forame } \\
\text { n }\end{array}$ & $\%$ & $\begin{array}{l}\text { No of } \\
\text { forame } \\
\text { n }\end{array}$ & $\%$ & $\begin{array}{l}\text { No of } \\
\text { forame } \\
\text { n }\end{array}$ & $\%$ \\
\hline $\begin{array}{l}\text { Median } \\
\text { crest }\end{array}$ & 01 & 1.30 & 01 & 1.28 & 02 & 1.29 \\
\hline $\begin{array}{l}\text { Posterior } \\
\text { surface }\end{array}$ & 76 & 98.7 & 77 & 98.7 & 153 & $\begin{array}{l}98.7 \\
1\end{array}$ \\
\hline Total & 77 & 100 & 78 & 100 & 155 & 100 \\
\hline
\end{tabular}

Table 3: Showing distribution of nutrient foramen in respect to zone of fibula

\begin{tabular}{|l|l|l|l|l|l|l|}
\hline Zone & \multicolumn{2}{|l|}{ Right (77) } & \multicolumn{2}{l|}{ Left (76) } & \multicolumn{2}{l|}{ Total149 } \\
\hline & Number & \% & Number & \% & Number & \% \\
\hline $\begin{array}{l}\text { Zone } \\
\text { I }\end{array}$ & 00 & 00 & 01 & 01.28 & 01 & 0.65 \\
\hline $\begin{array}{l}\text { Zone } \\
\text { II }\end{array}$ & 75 & 97.40 & 77 & 98.72 & 152 & 98.06 \\
\hline $\begin{array}{l}\text { zone } \\
\text { III }\end{array}$ & 02 & 02.60 & 00 & 00 & 02 & 1.29 \\
\hline & 77 & 100 & 78 & 100 & 155 & 100 \\
\hline
\end{tabular}

\section{Direction of foramina}

The direction of nutrient foramina was not showing any deviation from normal anatomical feature even in single case throughout the study. All the foramina were directed upwards or toward the upper end of fibula as shown in [Figure 1]. As shown in [Table 4], the mean total length of fibula was found to be $35.37 \mathrm{~cm}$ in right and $35.46 \mathrm{~cm}$ in left fibula; and mean distance from proximal end of fibula to the nutrient foramen was found to be $17.62 \mathrm{~cm}$ for right and $16.38 \mathrm{~cm}$ for left fibula and the foraminal index was found to be $49.74 \%$ on right fibula and $46.23 \%$ on left fibula. Therefore, an average the total mean length of fibula was found to be $31.41 \mathrm{~cm}$; and mean distance from proximal end of fibula to the nutrient foramen was found to be $17 \mathrm{~cm}$ and the mean foraminal index was found to be $47.99 \%$.

Table 4: Showing mean values of statistical measurements of fibula

\begin{tabular}{|l|l|l|l|}
\hline Parametre & Right 75 & Left 75 & Total 150 \\
\hline Mean total length & $35.37 \mathrm{~cm}$ & $35.46 \mathrm{~cm}$ & $35.41 \mathrm{~cm}$ \\
\hline $\begin{array}{l}\text { Distance from } \\
\text { proximal end to } \\
\text { NF }\end{array}$ & $17.62 \mathrm{~cm}$ & $16.38 \mathrm{~cm}$ & $17 \mathrm{~cm}$ \\
\hline Foraminal Index & $49.74 \%$ & $46.23 \%$ & $47.99 \%$ \\
\hline
\end{tabular}

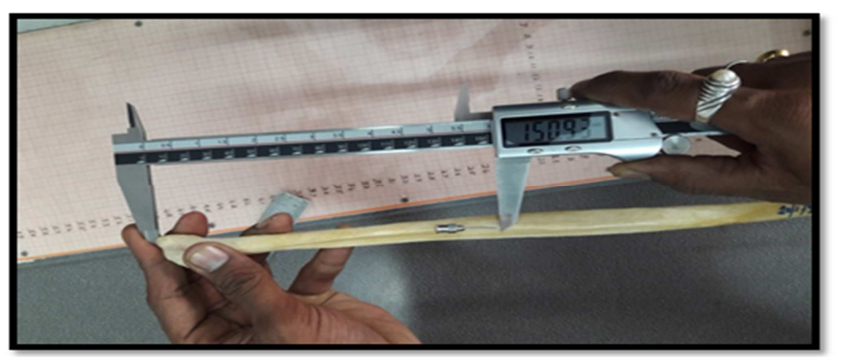

Figure 1: distance of Nutrient foramen in fibula measuring from proximal end 


\section{Akhari d Chavda, Variations of Nutrient Faramen of Filula in Saurashtra Regian}

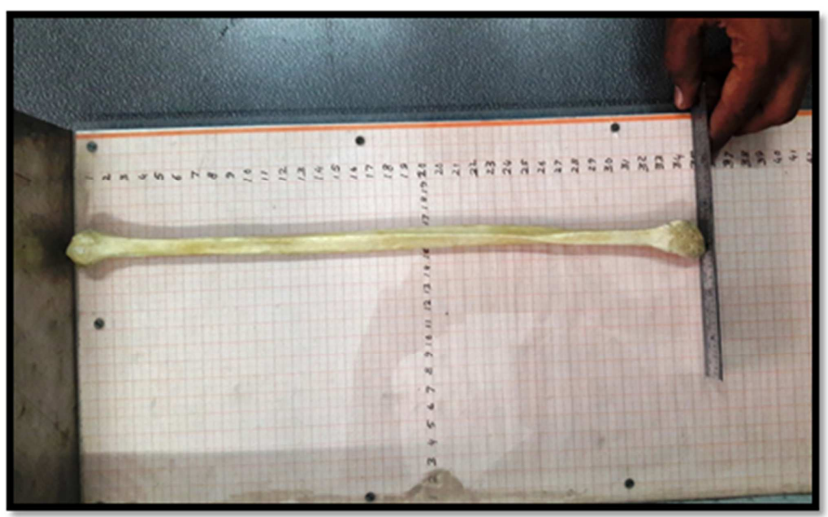

Figure 2: measuring Total length of fibula

\section{Discussion \& Conclusion}

\section{Number of nutrient foramina}

In the present study, a single nutrient foramen had a higher percentage $(96.67 \%)$ in the fibula bones, compared to that of double $(3.33 \%)$, and no nutrient foramen (\%). Many studies reported a percentage approximately similar to that of our study by Kizilkanat E and by Kumar S. ${ }^{[13,14]}$ The range of occurrence of double foramina varied from $13 \%$ by Kirschner $\mathrm{MH}^{[15]} 26 \%$ by Kumar $\mathrm{S},{ }^{[14]}$ and $42 \%$ by Mysorekar VR. ${ }^{[7]}$ Also, some reported the absence of nutrient foramina in some bones by Joshi $\mathrm{H},{ }^{[12]}$ and by Kizilkanat $\mathrm{E} ;{ }^{[13]}$ which is in accordance to the present study as $0 \%$ of fibula observed was without nutrient foramen.

\section{Direction of nutrient foramina}

In present study, all of the nutrient foramina in fibula were directed proximally (away from the growing ends) which was similar to the study by Kumar, et al. ${ }^{[14]}$

\section{Position of nutrient foramina}

In our study, most of nutrient foramina were located along the middle third of the fibula followed by lower third and then upper third, which were correlated with other studies by Kizilkanat E and by Nagel A. ${ }^{[8,13]}$ Similar findings had been reported by Kizilkanat, et al. ${ }^{[13]}$ and Kumar, et al. ${ }^{[14]}$

\section{Clinical relevance}

Position and number of the nutrient foramina in long bones is very important in orthopedic surgical procedures like joint replacement therapy, fracture repair, bone grafts and vascularized bone microsurgery. ${ }^{[13]}$ Injury to the nutrient artery at the time of fracture, or at subsequent manipulation, may be a significant factor predisposing to faulty union. The levels of osseous section are selected according to the localization of the diaphyseal nutrient foramina in order to preserve diaphyseal vascularization of the recipient to support the consolidation with the osseous graft. ${ }^{[16]}$

\section{References}

1. Krishna Garg. BD Chaurasia's Hand Book of General Anatomy. Blood supply of bones. 4th ed. 2011. CBS Publishers and Distributors Pvt. Ltd:43-44.

2. Longia GS, Ajmani ML, Saxena SK, Thomas RJ. Study of diaphyseal nutrient foramina in human long bones. Acta Anat. 1980;107:399- 406.

3. Sendemir E, Cimen A. Nutrient foramina in the shafts of lower limb long bones: situation and number. Surg Radiol Anat. 1991; 13:105-8.

4. Standring S. Gray's Anatomy, 40th ed. CHURCHILL LIVINGSTONE ELSEVER, 2008:798.

5. Bokariya P, Gudadhe D, Kothari R, Murkey PN, Shende MR Comparison of humerus and femur with respect to location and number of nutrient foramina. Indian Journal of Forensic Medicine and Pathology. 2012;5(2):79-81.

6. Henderson RG. The position of the nutrient foramen in the growing tibia and femur of the rat. J Anat. 1978; 125(3):593-9.

7. Mysorekar VR. Diaphysial nutrient foramina in human long bones. J Anat. 1967;101(4):813-22.

8. Nagel A. The clinical significance of the nutrient artery. Orthop Rev 1993; 22:557-61.Page 83 VOL. 14 | NO. 1 | ISSUE 53 | JANMAR 2016

9. Dyankova S. Vascular anatomy of the radius and ulna diaphyses in their reconstructive surgery. Acta Chir Plast 2004; 46:105-9.

10. Choi SW, Kim HJ, Koh KS, Chung IH, Cha IH. Topographical anatomy of the fibula and peroneal artery in Koreans. Int J Oral Maxillofac Surg 2001;30:329-32.

11. Schiessel A, Zweymuller K. The nutrient artery canal of the femur: a radiological study in patients with primary total hip replacement. Skeletal Radiol 2004;33:142-9

12. Joshi H, Doshi B, Malukar O. A study of the nutrient foramina of the humeral diaphysis. NJIRM 2011;2:14-17.

13. Kizilkanat E, Boyan N, Ozsahin ET, Soames R, Oguz O. Location, number and clinical significance of nutrient foramina in human long bones. Ann Anat. 2007;189:87-95.

14. Kumar S, Kathiresan K, Gowda MST, Nagalaxmi. Study of diaphyseal nutrient foramina in human long bones. Anat Karnataka.2012;6(2): 66-70.

15. Kirschner MH, Menck J, Hennerbichler A, Gaber O, Hofmann GO. Importance of arterial blood supply to the femur and tibia transplantation of vascularized femoral diaphiseal and knee joints. World J. Surg., 1998; 22: 845-52.

16. Wavreille G., Remedios, Dos C., Chantelot C. Anatomic bases of vascularized elbow joint harvesting to achieve vascularised allograft. Surg. Radiol. Anat., 2006; 28: 498

Copyright: ( ) the author(s), publisher. Academia Anatomica International is an Official Publication of "Society for Health Care \& Research Development". It is an open-access article distributed under the terms of the Creative Commons Attribution Non-Commercial License, which permits unrestricted non-commercial use, distribution, and reproduction in any medium, provided the original work is properly cited.

How to cite this article: Akbari VJ, Chavda SR. A Study on Variations of Nutrient Foramen of Fibula in Saurashtra Region with its Clinical Relevance. Acad. Anat. Int. 2019;5(1):68-70.

DOI: dx.doi.org/10.21276/aanat.2019.5.1.15

Source of Support: Nil, Conflict of Interest: None declared. 